He was first employed in the Lancashire textiles industry and later by the then Anglo-Iranian Oil Co. at Abadan. Mr. Sellers returned to Great Britain in 1938 and joined the staff of the Manchester Oil Refinery, Ltd., and was its refinery superintendent at the time of his appointment in 1948 to a University lectureship in the then newly established Department of Chemical Engineering at Cambridge. Mr. Sellers had previously had some experience of teaching as a part-time lecturer at the College of Technology, Manchester, and from the start was able to play a large part in the planning of the courses and the general organization of the Cambridge School. His research interests have been mainly in the field of distillation processes, including processes operating at very low temperatures. Mr. Sellers has been an active member of the Institution of Chemical Engineers, being on both its Board of Examiners and its Education Committee. He has also been much interested in furthering the co-operation of industry with universities in matters of education, and in the past few years has run two successful 'practice school' courses, first at the Stanlow Refinery of the Shell Refining and Marketing Co., Ltd., and secondly at the Royal Ordnance Factory, Bridgwater. It is expected that he will take up his new duties at Swansea next October.

\section{Geological Society: Awards for 1955}

THE Council of the Geological Society has made the following awards for 1955: Wollaston Medal to Sir Arthur Truernam for his outstanding and varied contributions to palæontology and stratigraphy and in particular for his palæontological work on the nonmarine lamellibranchs of the Coal Measures; this latter work has initiated and led to fundamental advances in palæontology and to the rationalization of British Coal Measures geology ; Murchison Medal to Dr. C. J. Stubblefield in recognition of his valuable contributions to palæontology and for his work on palæozoic stratigraphy; Lyell Medal to Mr. W. N. Edwards, keeper of geology in the British Museum (Natural History), in recognition of his distinguished work in the palæobotanical field ; Bigsby Medal to Dr. P. E. Kent for his contributions to the palæogeography and stratigraphy of England and Wales and his researches in Central Africa and Persia; Wollaston Fund to Mr. J. M. Edmonds for his contributions to the history of geology and the geology of the Oxford district; Murchison Fund to Mr. R. Casey for his illuminating work on the Aptian and Albian strata of southern England; a moiety of the Lyell Fund to Dr. P. A. Sabine for his petrological work, especially in the Assynt area of Scotland; another moiety of the Lyell Fund to Dr. W. Bullerwell for his work in applied geophysics and in particular for his contributions to the gravimetric survey of Great Britain.

\section{Royal Astronomical Society: Awards}

ThE following medal awards of the Royal Astronomical Society have been made : Gold Medal, Prof. Dirk Brouwer, director of the Yale University Observatory, for his outstanding contributions to celestial mechanics; Eddington Medal, Prof. H. C. van de Hulst, of the Observatory, Leyden, for his prediction of the $21-\mathrm{cm}$. line radiation of neutral hydrogen, and for his share in its detection and observation and in the theoretical interpretation of the observations.

\section{Some Exhibits in the Cavendish Laboratory Museum}

AN illustrated account of some of the instruments made by Elliott Brothers, Ltd., which are in the Museum of the Cavendish Laboratory, Cambridge, has appeared in the Elliott Journal (2, No. 1; 1954). In an earlier article in the same journal (1, No. 1; 1951) reference was made to some of the apparatus constructed for Maxwell, Rayleigh and others by the firm, but a recent rearrangement of the apparatus in the Museum has suggested a fuller account of the more notable Elliott instruments collected there. Maxwell's colour top and his real-image stereoscope are described, and some interesting details are given of his experiments and results using the well-known disk apparatus for the determination of the viscosity of gases, which was constructed for him by Mr. Becker and described in Maxwell's Bakerian Lecture to the Royal Society on February 8, 1866. Maxwell was succeeded as Cavendish professor by Lord Rayleigh, whose research was concentrated on the provision and maintenance of high-precision electrical standards. Elliott Brothers made some of the earliest substandard resistance boxes calibrated in terms of the British Association ohm, and later assisted in the re-determination of the ohm by Lord Rayleigh and Mrs. Sidgwick by constructing the well-known spinning-coil apparatus used in that series of experiments. A photograph of the apparatus and references to the original papers are included in the article.

\section{Geological Background of the lyatayet Site, Alaska}

IN 1951 Giddings published his discovery of a blade, core and burin industry, which he called the Denbigh flint complex. This preceded and differed fundamentally from the known Eskimo occupations of Alaska, ineluding the palæo-Eskimo one of which Ipiutak is a part, and its importance is due not only to its age but also to its possible Upper Palæolithic ancestry. A description of the recent geology of the site of the discovery, with an attempt to correlate it with recent deposits elsewhere in Alaska, has been published as a paper by D. M. Hopkins and J. L. Giddings, jun., in Vol. 119, No. 2 of the Smithsonian Miscellaneous Collections (Pub. 4110. Pp. ii $+3 a+$ 4 plates. Washington, D.C. : Smithsonian Institution, 1953). On archæological grounds, the authors believe that the industry is older than the related one, lacking burins, found at Trail Creek, Seward Peninsula, and dated by radiocarbon at about 4000 B.c. Two alternative correlations are suggested: one would give the Denbigh industry an age greater than 10,000 B.C., and the other, which the authors prefer, would date it at about 6500 B.C. The paper illustrates the specialized knowledge required for the interpretation of Quaternary geology in these regions, since it includes such unexpected features as the correlation of forty feet of aggradation in a valley with a period of low rather than high sea-level.

\section{Nitrogen Metabolism of Ripening Fruit}

IN a recent study of the nitrogen metabolism of apple fruits, A. C. Hulme (J. Exp. Bot., 5, No. 14, 159 ; 1954) has found that a close parallelism occurs in the trend of respiration-rate and the ratio protein nitrogen/non-protein nitrogen, both in attached fruits and in fruits harvested at various stages of development and stored for several months at $12^{\circ} \mathrm{C}$. In detached fruits the fall in respiration which occurs immediately after picking is only accompanied by a 